\title{
Ta ledelsen tilbake!
}

\author{
En kamp mot de store styringsideologiene tar blikket bort fra det man faktisk kan gjøre noe med. \\ Helsevesenet reformeres best nedenfra. I dag lider helsevesenet av uhensiktsmessige tilpasninger \\ og manglende ledelse i klinisk virksomhet.
}

Vegar Bruun Wyller og hans legekolleger har skrevet en spennende kronikk om dagens styringsideologi i helsetjenesten (1). Dette er en etterlengtet diskusjon, og det er alltid prisverdig når noen ser skjevt på rådende styringsideologier - særlig de som fremstår som tverrpolitiske.

New public management (NPM) har hatt en rekke negative effekter som har påvirket offentlig administrasjon (2). Konkurranse, kontroll og reguleringsregimets bakside er opplevelsen av mistillit og demotivasjon, ikke bare i helsevesenet, men også for den offentlige sektor generelt. Men new public management er en samlebetegnelse som tilslører mer enn den avdekker. Vi snakker her om en rekke sammenfallende reformer og styringsinitiativ med ulike opphav og forsvarere (3). Intensjonene med de ulike reformene feiler vel så ofte fordi vi får tilpasninger som ikke var intendert. Det gis medisin mot noe, og så oppstår det bivirkninger som igjen krever sin medisin (4).

Nye ideer er som regel ikke vellykket $i$ kraft av at de er uprøvde (5).

\section{Enhetlig ledelse}

En reform jeg savner omtalt, er NPM-reformen om enhetlig ledelse. I 1999 kom et lovvedtak om at alle sykehus skulle ledes av en profesjonsnøytral leder med fullt drifts- og budsjettansvar. Årsaken til denne reformen var sprikende budsjettansvar ved avdelingene på grunn av todelt ledelse mellom leger og sykepleiere. Enhetlig ledelse ble møtt med store protester, men så stilnet kampene. Sykehusene tilpasset seg. Gradvis skilte legeseksjoner og sykepleieseksjoner lag (4). Istedenfor å få en profesjonsnøytral leder, var det det motsatte som skjedde. Legene fikk sine egne små seksjoner og avdelinger, og det samme med sykepleierne (6).

Dette har ført til en legeavmakt, som kronikken er et utrykk for, men som også kan ses på som legenes abdisering (7). Det er ikke antall ansatte i direktoratet eller avvikling av de regionale helseforetakene som vil endre hverdagen for legene i klinisk arbeid, men at legene selv er med og tar det totale lederansvaret.

Tverrfaglig samarbeid - mer ledelse Den kjente helsetjenesteforskeren Stephen Shortell uttalte sist han var på norgesbesøk, at fremtidens helsevesen ikke er organisert rundt legekontoret. Den tradisjonelle måten å organisere sykehus på, er å oppdele syke- huset $\mathrm{i}$ enheter som følger medisinfagets spesialiteter. Dette gjør sykehuset stadig mer fragmentert, ettersom medisinfaget blir mer spesialisert og koordinering på tvers mellom fag og mellom ulike profesjoner svikter. Fremtidens helsevesen er organisert rundt pasienten og krever tett samarbeid med alle profesjoner i sykehuset. Hovedinnvendingen mot Wyller og hans legekolleger er ikke deres angrep på noen av elementene ved de nye styringsideologiene, men snarere at de fremstår som en interessegruppe for legene. Hvor er alle de andre profesjonene og yrkesgruppene ved sykehuset?

Sykepleieenhetene blir preget av stort kontrollspenn, og legeenhetene av mangel på stedlig ledelse med få leger på flere ulike lokalisasjoner. Ved å samle disse enhetene ville man kunne lage tilstrekkelig store enheter ved de ulike lokalisasjonene, og sikre stedlig og profesjonsnøytral ledelse.

\section{«l dagens organisering er legene i ferd med å organisere seg ut av sykehuset»}

Samtidig vil en mer tverrfaglig virksomhet kreve mer ledelse. I dagens organisering er legene i ferd med å organisere seg ut av sykehuset. Mens legene lager stadig mindre legeseksjoner, lager sykepleierne store avdelinger hvor de virkelige store driftsavgjørelser tas. Legene konsentrerer seg om faget. I dag er avdelingsledere med legebakgrunn primært klinikere. $40 \%$ av alle avdelingsledere ved landets sykehus er leger. Halvparten av disse bruker mindre en $50 \%$ av sin tid til ledelse. Kun $5 \%$ av sykepleieledere har tilsvarende tall (8). Legelederne begrunner dette med at de må være i klinisk arbeid for å beholde sin autoritet som leder (9). Sykepleierne er lei av legeledere som ikke tar totalansvaret, men bare konsentrerer seg om faget. Legene trives godt med å få slippe vaktplaner, sengelogistikk og medarbeidersamtaler.

\section{Ledelseskraft}

I dag er sykehusene blitt store, kompliserte driftsenheter, driftsbudsjettene er doblet.
Enorme ressurser forvaltes, omfattende lovverk og pasientrettigheter er blitt pålagt sykehusene. Det er ikke fritt for at vi er mange som kunne ønske oss 10-20 år tilbake. Mulighetene er mye større i dag, men det krever ledelseskraft og klok organisasjonsutvikling helt ned i møtet med pasienten. Et godt eksempel på en slik leder er avdelingsleder Bjørn Atle Bjørnbeth som nylig fikk Legeforeningens lederpris.

Her er ti råd til leger som vil ta ledelsen tilbake:

1) Ta ledelsen - fullt og helt! La ledelse og organisering bli en egen spesialisering $\mathrm{i}$ legeutdanningen.

2) Ta arbeidsmiljøet på alvor - følg opp medarbeiderundersøkelser og ta vare på dine kolleger.

3) Ta pasientsikkerhet på alvor. Når holdningen til uheldige hendelser er åpenhet og ærlighet, vil behovet for kontroll bli mindre.

4) Kom ut av skyttergraven, tenk prioritering for hele sykehuset ikke bare din egen seksjon.

5) Hold budsjettet. Hvor vondt det enn er for oss alle, så kan vi ikke bruke mer ressurser enn det vi har fått tildelt. Noe annet er uredelig.

6) Tenk tverrfaglig - lag hensiktsmessige enheter som også inkluderer drift - ikke bare legefaget. Det vil gi enheter som faktisk får innflytelse.

7) Tenk helhet - det er ikke alltid at en ny legestilling er det eneste som vil øke pasientbehandling.

8) Ta ansvar for lederen. Ledelse er vanskelig, og leger er ikke kjent for å gjøre dette lettere. Det er en utbredt skyldplassering oppover uten at man erkjenner eget ansvar. Vi får som regel de lederne vi fortjener.

9) Vis lojalitet til dem som ikke er til stede. Medarbeidernes syn skal løftes frem av lederen i ledermøter - det man så er blitt enig om, fremheves i møte med 
medarbeiderne. Ved å ha lojalitet både nedover og oppover blir diskusjonene ærlige, og vi slipper alle omkampene. Lojalitet til lederen hindrer ikke lojalitet til medarbeidere.

10) Tenk globalt - handle lokalt. Vi skal ha store visjoner, men de virkelige endringene og påvirkningsmulighetene har vi i nærmiljøet. Hva kan du gjøre for å bedre driften rundt deg?

\section{Lars Erik Kjekshus}

l.e.kjekshus@medisin.uio.no

Lars Erik Kjekshus (f.1968) er statsviter med doktorgrad i organisasjon og ledelse av sykehus. Han er nytilsatt leder for HR-utvikling ved Oslo universitetssykehus i HR-Direktørens stab og forskningsleder og førsteamanuensis II ved Avdeling for helseledelse og helseøkonomi,
Institutt for helse og samfunn ved Det medisinske fakultet, Universitetet i Oslo.

Forfatter har fylt ut ICMJE-skjemaet og oppgir ingen interessekonflikter.

\section{Litteratur}

1. Wyller VB, Gisvold SE, Hagen E et al. Ta faget tilbake! Tidsskr Nor Legeforen 2013; 133: 655-9.

2. Christensen T, Lægreid P. The Ashgate Research Companion to New Public Management. Farnham: Ashgate, 2010.

3. Kjekshus LE, Veggeland F. State regulatory capacity: experiences from public sector reforms in Norway. Public Adm 2011; 89: 1568-84.

4. Kjekshus LE. Norske sykehus er geriatriske pasienter. I: Melberg HO, Kjekshus LE, red. Fremtidens Helse-Norge. Bergen: Fagbokforlaget, 2012: 15-26.

5. March JG. Research on organizations: hopes for the past and lessons from the future. Nordiske Organisasjonsstudier 1999: 1: 69-83.

6. Lippestad J, Harsvik T, Kjekshus LE. Ledelse $i$ et sykehus i omstilling. En oppsummering av et følgeforskningsprosjekt ved Akershus Universitetssykehus i perioden 2006-2010. Oslo: SINTEF.
2011. www sintef no/Publikasjoner-SINTEF/ Publikasjon/?pubid=SINTEF+A18917 (11.4.2013).

7. Kjekshus LE, Byrkjeflot H, Torjesen DO. Organisering og ledelse av sykehus etter NPM - legenes tilbaketrekning? I: Tjora AH, Melby L, red. Sammen for helse: kunnskap, kommunikasjon og teknologi i helsetjenestens samhandling. Oslo: Gyldendal Akademisk, 2013, under trykking.

8. Kjekshus LE Bernstrøm VH. Helseforetakenes interne organisering og ledelse INTORG 2009. Helseøkonomisk forskningsprogram, skriftserie nr. 4. Oslo: Universitetet i Oslo, 2010.

www.med.uio.no/helsam/forskning/nettverk/hero/ publikasjoner/skriftserie/2010/hero_2010 04.html (11.4.2013)

9. Spehar I, Frich JC, Kjekshus LE. Clinicians' experiences of becoming a clinical manager: a qualitative study. BMC Health Serv Res 2012; 12: 421.

Mottatt 22.3. 2013 og godkjent 5.4. 2013. Medisinsk redaktør Hanne Støre Valeur.

Publisert først på nett. 